\section{Framing and fighting: The impact of conflict frames on political attitudes}

Journal of Peace Research 2019, Vol. 56(6) 737-752

(C) The Author(s) 2019

Article reuse guidelines:

sagepub.com/journals-permissions DOI: $10.1177 / 0022343319826324$ journals.sagepub.com/home/jpr
Daphna Canetti

School of Political Science, University of Haifa

Ibrahim Khatib

Berlin Graduate School for Social Sciences, Humboldt University of Berlin
Aviad Rubin

School of Political Science, University of Haifa

Carly Wayne

Department of Political Science, University of Michigan

\begin{abstract}
How does the subjective conceptual framing of conflict impact the warring parties' attitudes towards political compromise and negotiation? To assess strategies for conflict resolution, researchers frequently try to determine the defining dispute of a given conflict. However, involved parties often view the conflict through fundamentally distinct lenses. Currently, researchers do not possess a clear theoretical or methodological way to conceptualize the complexity of such competing frames and their effects on conflict resolution. This article addresses this gap. Using the IsraeliPalestinian conflict as a case study, we run a series of focus groups and three surveys among Jewish citizens of Israel, Palestinian citizens of Israel (PCIs), and Palestinians in the West Bank. Results reveal that three conflict frames are prominent - material, nationalist, and religious. However, the parties to the conflict differ in their dominant interpretation of the conflict. Jewish Israelis mostly frame the conflict as nationalist, whereas Palestinians, in both the West Bank and Israel, frame it as religious. Moreover, these frames impact conflict attitudes: a religious frame was associated with significantly less willingness to compromise in potential diplomatic negotiations among both Jewish and Palestinian citizens of Israel. Interestingly, differing frames had no significant impact on the political attitudes of West Bank Palestinians, suggesting that the daily realities of conflict there may be creating more static, militant attitudes among that population. These results challenge the efficacy of material solutions to the conflict and demonstrate the micro-foundations underpinning civilians' conflict attitudes and their implications for successful conflict resolution.
\end{abstract}

\title{
Keywords
}

conflict, conflict resolution, framing, Israeli-Palestinian conflict, perception

\section{Framing and fighting}

Why does violent conflict persist? To outside parties looking in at protracted conflicts around the world, the material concerns at the core of the conflict seem fundamentally resolvable, if difficult to implement in practice. Conversely, to those directly involved in the conflict, differences often appear totally irresolvable. Why are the views from the outside and inside so different? We contend that involved parties often view the conflict through distinct conceptual frames from both outsiders and from each other. As a result, they can fail to speak the same language on everything from the origins of the conflict, to the issues under dispute, to avenues for its possible resolution.

Attempts to categorize conflict types (Caplan, 2011; Dowty, 2005; Tessler, 2009) in order to develop viable conflict resolution strategies are important but may overlook variation in perceptions among and between the parties that could inhibit successful conflict resolution. It is not necessarily the 'objective' third-party

Corresponding author: dcanetti@poli.haifa.ac.il 
understanding of the conflict type that matters most, but the way in which the groups and individuals involved perceive the conflict. These conceptual frames can be best understood as a way of constructing meaning (Snow $\&$ Benford, 1988), implying that the conflict 'reality' is in fact constructed - and contested - by the parties involved (Benford \& Snow, 2000). Frames are used to diagnose the conflict (e.g. What type of conflict is this? What is at stake? Who am I fighting?). They also entail downstream effects on behavior, leading to different prognostic assessments about the conflict (Benford \& Snow, 2000).

The Israeli-Palestinian conflict is an important laboratory for evaluating the impact of these conflict frames on political attitudes. This conflict has alternatively been framed as: (1) a material conflict over scarce natural resources in a tiny, resource-starved land (Dowty, 2005; Selby, 2003); (2) a nationalist conflict between competing ethnic groups with distinctive nationalist ideologies for territorially based self-determination (Ghanem, 2010); or (3) a budding religious war between two religious communities (Maoz, 2014; Inbari, 2012; Rubin, 2014). Using a combination of focus groups and surveys of respondents in Israel and the Palestinian Territories, we study the prevalence of these frames among Jewish citizens of Israel, Palestinian citizens of Israel (PCIs), and West Bank Palestinians and their impact on willingness to compromise.

This research results in three main findings. First, Palestinians and Israelis frame the conflict distinctively, even after accounting for the potentially confounding role of political ideology, partisanship, and religiosity. Palestinians (in both Israel and the West Bank) view the conflict as religious (to varying degrees), while Jews view the conflict as nationalist. Thus, the groups frame the conflict differently from each other (nationalist vs. religious) and from outside observers (e.g. as fundamentally identity-based rather than material). Second, the way the conflict is framed is significantly associated with willingness to compromise to resolve the conflict: those with a religious frame are less supportive of compromise than those with a material frame. Third, West Bank Palestinians' attitudes toward compromise are both more militant than their Israeli (both Jewish and Palestinian) counterparts and more static - that is, they are unaffected by conflict frame. This suggests that the explanatory power of conflict frames is qualified and contingent on real life circumstances related to the occupation, such as higher levels of daily exposure to violence and recurrent humiliating experiences.

This study adds to the conflict literature in four key ways. First, this study complements international relations scholarship, which has identified various realpolitik factors as determinants of the length and intractability of protracted conflicts, by exploring the way the psychological micro-foundations of civilian political attitudes can stoke or ease these conflicts. Second, we also contribute to the body of research on the complex role of belief systems and attitudinal frames in the prevalence and severity of violent conflict. Third, this study problematizes the assumption that a conflict can be defined as one coherent 'type' or that the understanding of this type is shared by all parties. This point is highly relevant for policymakers and practitioners, as the presence of multiple, competing conflict frames may necessitate more complex conflict resolution strategies than the traditional emphasis on material approaches (e.g. the distribution of material goods and resources).

Fourth, this study adds a layer of understanding to previous research on the Israeli-Palestinian conflict. For one, that the parties to the conflict frame it in different ways - national on the Jewish Israeli side and religious on the Palestinian side - implies a need to direct effort to exploring the causes and effects of this discrepancy on strategies for reconciliation. In addition, the finding that Palestinians and Jews in Israel hold different frames but are still more willing to compromise compared with West Bank Palestinians, regardless of the frame held by the latter, suggest that other important dynamics of the conflict, such as its deeply asymmetric nature and extensive exposure to violence, may broadly harden the attitudes of the weaker population to compromise (Hirsch-Hoefler et al., 2014). The distinction between different conflict frames may thus have less of an impact as conflict intensity increases.

\section{Material vs. identity-based frames of conflict}

Rationalist approaches to conflict rely on a variant of realistic group conflict theory to argue that the issues triggering political violence are material - rooted in rational competition over scarce resources (e.g. land, oil, water). Essentially, it is zero-sum competition over material assets that promotes intergroup conflict (Campbell, 1965; Harvey et al., 1961). If competition over tangible resources could somehow be eroded, the 'side-effects' of the intergroup competition - prejudice and violence should dissipate. Using this frame, violence and conflict are situational and will wane in the absence of disputes over the distribution of resources. In other words, if a material resource is contested due to its tangible value (Carter, 2010; Goertz \& Diehl, 1992), a bargaining space should theoretically exist (Fearon, 1995). This assumption underlies conflict resolution practitioners' 
frequent advancement of proposals that 'expand the pie' through incentives or formulation of equitable 'split-thedifference' compromises. However, these solutions often do not account for identity-based sources of conflict that may be less responsive to material incentives and less amenable to compromise.

However, parties in conflict are often fighting over more than just material concerns. A competing theory of intergroup conflict, social identity theory (Tajfel $\&$ Turner, 1982), argues that material competition is not the underlying reason for conflicts; all that is required for conflict are distinctive group identities that trigger ingroup favoritism, out-group prejudice and violence even without resource competition. Even when material conflicts are manifest, intergroup identity conflict is still required for conflict to actually break out (Tajfel \& Turner, 1982). Identity related issues thus go beyond the material-based core of the rational-choice model, challenging its optimistic predictions regarding the tractable dissipation of conflict.

\section{Identity-based explanations: Nationalism and religion}

Material disagreements over scarce resources are clearly present in most political conflicts. Ethnic differences or the presence of nationalism are generally not alone enough to engender violent conflict. Material factors such as poverty, political instability, rough terrain, and the presence of large populations are often better predictors for civil war onset than is the number of ethnic groups in a country (Fearon \& Laitin, 2003) or its socalled 'ethno-linguistic fractionalization' (Alesina et al., 2003). Similarly, rebels' ability to extract resources and recruit soldiers may be more important in explaining civil war onset than relative repression or the presence of ethnic dominance (Collier \& Hoeffler, 2004).

These accounts, however, do not explain why material conflicts nonetheless frequently crystallize along identity lines. Although not all wars are so-called 'identity wars', those that are may stem from different causes and require different solutions than those that are not (Sambanis, 2001). For example, land may hold symbolic significance for conflicting parties, making the land essentially indivisible and closing bargaining spaces that might have otherwise existed (Goddard, 2006). This symbolic significance can stem from either nationalist or religious attachment to a contested resource. ${ }^{1}$

\footnotetext{
${ }^{1}$ Admittedly, national and religious conflicts do not represent an exhaustive list of potential identity-based conflicts. Global conflicts
}

\section{Nationalism and conflict}

Nationalism has long been theorized to play a role in exacerbating both the prevalence and severity of political conflict. Benedict Anderson (1983: 50) describes nationalism as the perception of 'a deep, horizontal comradeship' among members of the nation, even in the absence of personal interaction. Nationalistic sentiments are thus rooted in group identity, individual psychology, and core human needs for attachment, community, security, group loyalty, and prestige (Druckman, 2001).

When directed towards the political sphere, nationalist doctrines hold that 'the political and national unit should be congruent' (Gellner, 1983: 80). When this principle is violated, and one or more populations do not have political representation congruent with their national identity, this can trigger conflict between groups (Cederman \& Girardin, 2007; Miller, 2005). Thus, at their core, nationalist conflicts are over the political control of a contested geographic space - a material issue. However, nationalism takes this material issue and imbues it with values rooted in group identity - this land is important not just because of material resources, but because it is the homeland of our people, and hence embedded with a sacred meaning for the nation (Smith, 2000).

Nationalist conflicts can thus be seen as combining elements of 'instrumental rationality' with a distinct form of 'value rationality' (Varshney, 2003). Instrumental rationality represents the traditional construction of rationality - a cost-benefit calculus designed to accomplish concrete goals, the pursuit of which will be abandoned or altered if the cost becomes too high (Varshney, 2003). However, value rationality operates differently; it includes a conscious belief whose value is calculated independently of its prospects for success. Values (such as abstract ideas about 'dignity' or 'self-respect') may allow, or even require, the embrace of very large personal sacrifices (Varshney, 2003). These identity- and valuebased components of nationalism suggest that, compared to material framing, nationalistic frames will be more resistant to compromise. The value-based components of nationalist conflicts - perceptions that a conflict is being fought not just for land but, perhaps, for dignity and self-determination as well - can lead individuals to support greater costs of fighting.

such as World War II or the Cold War included a strong ideological element, for example. Nevertheless, conflicts in the modern era, especially protracted (or intractable) ones, have emerged primarily in relation to nationalistic or religious narratives (Brecher, 2017). 


\section{Religion and conflict}

The relationship between religion and political violence has also been deeply contested (Canetti et al., 2010). There is no shortage of examples of political violence perpetrated in the name of religion and scholars have argued that religion remains a central component of modern political conflicts (Huntington, 1993; Juergensmeyer, 1993; Isaacs, 2016). However, religion is also a primary source of empathy, compassion, and nonviolence. What explains why religion can be 'either violent or irenic, a source of terrorism or a contributor to the rule of law?' (Philpott, 2007: 505). Untangling this 'ambivalence of the sacred' (Appleby, 1999) and incorporating religion into international relations theory is thus a central challenge for conflict studies (Fox \& Sandler, 2004).

There are three ways in which religion can affect willingness to compromise on core grievances and so impact political conflict. Compared to material, and even nationalist, claims religious grievances are likely to be more deeply held (Seul, 1999), difficult to divide (Svensson, 2007), and less easily subject to trade-offs (Atran, Axelrod \& Davis, 2007). ${ }^{2}$ Religious identity and religious beliefs are also frequently a primary identifier for individuals, making compromise on religious issues difficult (Seul, 1999). Intangible in nature, sacred spaces - defined by both their centrality and exclusivity in religious life - are particularly difficult to split up because they are cohesive, have unambiguous boundaries, and cannot be substituted or exchanged for another good or issue (Hassner, 2009). Importantly, the issue indivisibility of sacred, religious spaces and values does not lie in the objective ability to divide the space (e.g. by making Jerusalem an international city), but in opposing sides' subjective perception that the issue is not divisible (e.g. the city is holy and is ours) (Goddard, 2006). The rationalist conception of issues as fundamentally divisible due to the multidimensionality of political conflict (e.g. Fearon, 1995) is thus less applicable to conflicts framed as religious.

\section{The Israeli-Palestinian conflict}

Asymmetric in nature, marked by a large power imbalance and a reality of inequalities, the Israeli-Palestinian conflict is one of the world's most deeply protracted conflicts (Brecher, 2017). Despite mutual attempts to engage in peacebuilding initiatives, the large number of Israelis and Palestinians who oppose making concessions is a crucial factor impeding policymakers' ability to

\footnotetext{
${ }^{2}$ In this work, the authors take a broad conception of sacred values that may also include things like 'the nation' or family.
}

negotiate for peace (Manekin, Grossman \& Mitts, forthcoming). It is thus vital to examine the psycho-political mechanisms underlying public opinion in this context. ${ }^{3}$

In this study, we investigate the role played by material, nationalist, and religious frames of the conflict in shaping willingness to compromise for peace, at both the group and individual levels. The Israeli-Palestinian conflict encompasses a significant material element - control over territory (Vasquez \& Valeriano, 2010; Rasler \& Thompson, 2006) - which is aggravated due to the relative limitation of this resource and its importance for another material concern: security. The disputed territory also has limited water and energy resources (Dowty, 2005; Selby, 2003). On the other hand, it can be viewed as a nationalist conflict between two ethnic peoples striving for political self-determination. In this view, the conflict developed as a modern dispute between two national movements, Jewish (as an ethnic group) and Palestinian, which came into struggle with the emergence of the Zionist movement in Europe in the mid19th century. Finally, the conflict can also be understood as a deeply rooted religious dispute between Jews and Muslims that emerged with the birth of Islam in the 7 th century. In this telling, the core of the conflict is uncompromised ownership over a sacred land that was granted to both people by contradictory divine covenants. Both parties are deeply committed to the holy sites in the Old City of Jerusalem/Al-Quds, the division of which is considered as the major obstacle to any future compromise (Maoz, 2014; Inbari, 2012; Fox \& Sandler, 2004). Recent empowerment of religious political discourse and agents, specifically the rise of Hamas (Dunning, 2015; Mishal \& Sela, 2006) and the prominence of the religious settler movement in Israel (Haklai, 2007; Rubin, 2014), also indicate the significance of this frame.

\section{Main hypotheses}

We contend that identity-based conflicts, as a category, call for different processes of compromise and reconciliation and are less directly amenable to compromise. However, whereas nationalist frames are based in identity, they are also inherently tied to land and territory, which

\footnotetext{
${ }^{3}$ Protracted conflicts around the world often share a number of elements. They are usually characterized by extensive exposure of civilians to political violence and perceived lack of resolvability, despite international interventions. Additionally, opposing interpretations of the conflict's origins and attributes are a constant source of tensions. Thus, findings from the Israeli-Palestinian conflict have important implications for other protracted conflicts around the world.
} 
may be more amenable to compromise than land framed as a sacred religious space. We thus hypothesize a gradation of the linkage between conflict framing and willingness to compromise: material, nationalist, and religious conflict framing. Namely, people who possess a material frame will be more willing to compromise compared to those possessing a nationalist framing, who will in turn, be more willing to compromise compared to those possessing a religious frame.

\section{Methods and design}

We advanced a two-phase analysis - focus groups and survey data - conducted separately among Jewish Israeli citizens, PCIs, and Palestinian inhabitants of the West Bank. ${ }^{4}$ Phase 1 consists of 14 focus group meetings. In Phase 1, we (a) identified the core themes and verified the frames respondents used as their lenses to view the conflict, (b) conducted discourse analysis to systematically summarize this information, and (c) constructed a conceptually validated conflict framing scale to be used in Phase 2. Phase 2 then consists of original surveys among 411 participants in Israel and the West Bank. We used analyses of variance and multiple regression models to (a) identify the distinct ways in which Jewish Israelis, PCIs, and West Bank Palestinians frame the conflict, (b) examine the impact of the different conflict frames on individuals' willingness to compromise for peace, accounting for relevant covariates such as ideology, partisanship, and religiosity, and (c) analyze the differential impact of these conflict frames across the national groups.

\section{Phase 1: Israeli and Palestinian focus groups}

Focus groups are well suited to collecting data on potentially sensitive information since they are less threatening for participants than one-on-one interviews. Focus groups are also an important tool for assessing the range of views and representations of an issue (Morgan, 1996), and for revealing points of contention and underlying group dynamics (Kapiszewski, Maclean \& Read, 2015). Finally, focus groups can be particularly useful in a mixed-methods research design as a survey pretest (O’Brien, 1993), helping to establish the salient dimensions of complex social stimuli (Lunt \& Livingstone, 1996) and improve measurement validity of survey instruments (Cyr, 2016). Merging these focus groups

\footnotetext{
${ }^{4}$ We did not conduct focus groups or surveys in the Gaza Strip due to security considerations. Thus, we cannot speak about the extent to which these results generalize to Palestinians residing in Gaza.
}

with survey work thus capitalizes on the strengths of both methods - focus groups for exploratory research and conceptual structure and surveys to help determine the prevalence of these attitudes among a broader population (Ward, Bertrand \& Brown, 1991).

\section{Methods}

Because it is important that these groups be structured such that participants feel safe to share information (Vaughn, Schumm \& Sinagub, 1996), we conducted separate focus groups for Jewish citizens of Israel, PCIs, and Palestinians in the West Bank. The focus groups were constructed based on the classic arrangement of six to eight participants who had not met before, meeting in a convenient setting for one to two hours with a member of the research team serving as a moderator. The moderator of each focus group spoke the group's language (Hebrew or Arabic) as a mother tongue, and the questions in each group were semi-structured and almost the same (adjusted only slightly for context), in order to avoid moderator bias.

Participants were from cities across Israel and the West Bank, and included 32 Jewish Israelis, 42 PCIs, and 37 West Bank Palestinians. In the West Bank sample, $83 \%{ }^{5}$ of participants were men, 95\% Muslim, 5\% Christian; 30\% described themselves as religious, $65 \%$ as traditional, and $5 \%$ as secular. The PCI sample was $78 \%$ men, $86 \%$ Muslim, and 14\% Christian, with $41 \%$ identifying as religious, $33 \%$ as traditional, and $26 \%$ as secular. Jewish Israelis included $69 \%$ men, with $62 \%$ of them identifying as primarily secular, $34 \%$ as religious, and $4 \%$ as traditional.

The participants in the focus groups were first asked to fill in a demographic background form. During the meetings, participants were asked their opinions on the nature of the Israeli-Palestinian conflict and the fundamental issues over which they believed Israelis and Palestinians were fighting. Examples include: What does the conflict mean to you? How do you see the PalestinianIsraeli conflict? What are the core issues over which the two sides are struggling? What type of conflict do you think the Israeli-Palestinian conflict is?

The sessions were recorded and transcribed by a member of the research team. Data were then analyzed using content analysis and thematic discourse analysis (Guest, Namey \& Mitchell, 2012) to help identify, analyze, and report patterns or themes within the data

\footnotetext{
${ }^{5}$ Gender imbalance was pronounced among Palestinians. In that society, it is often difficult to find a large number of women to participate in political research, given its conservative nature.
} 


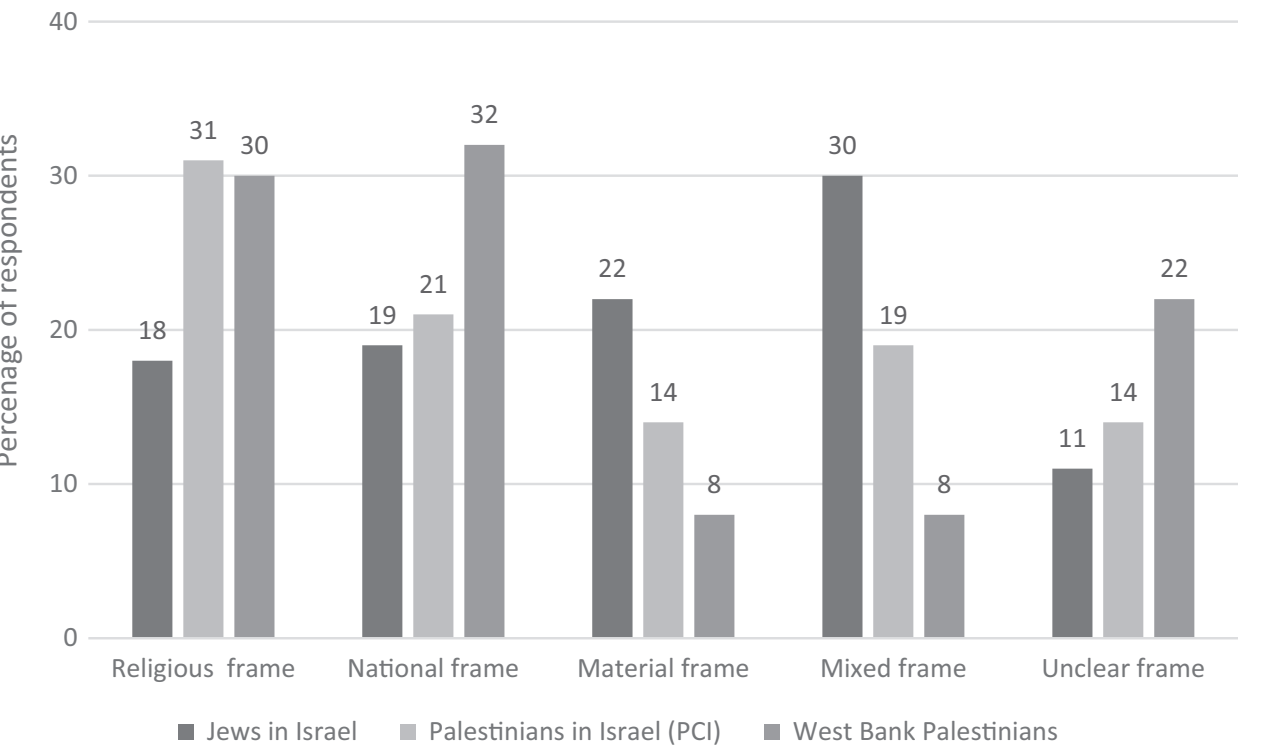

Figure 1. Prevalence of conflict frame by group (Focus groups)

Figure 1 plots the percentage of Jewish Israelis, PCIs, and West Bank Palestinians who categorize the conflict as predominantly material, religious or national in nature in the focus groups. Respondents with mixed or unclear frames are charted separately. Note that this focus-group sample, is non-representative, with purposive oversampling of certain segments of each population.

(Braun \& Clarke, 2006). Themes were identified using qualitative assessments of 'prevalence' and 'keyness' of words and phrases mentioned by the participants (Braun $\&$ Clarke, 2006). A detailed overview is in Online appendix 1 (see Table A1).

\section{Content analysis}

After identifying the core themes respondents discussed, we conducted basic content analysis to summarize this information quantitatively (Onwuegbuzie et al., 2009). Combining the three focus groups: $24 \%$ of participants saw the conflict as nationalist, $27 \%$ as religious, $14 \%$ as material and $18 \%$ as a combination of several elements, while $17 \%$ did not have a clear answer or could not answer the question (Figure 1). ${ }^{6}$

Overall, Jewish Israelis were most likely to possess some type of mixed frame for viewing the conflict usually combining nationalist and material elements. In contrast, for Palestinians in Israel, a religious frame was much more prevalent. Nationalist and religious frames occurred in relatively equal numbers in the West Bank Palestinian context.

Moreover, the chosen frame and the issues mentioned by the participants frequently covaried. For example,

\footnotetext{
${ }^{6}$ Near the end of the focus group session, each respondent was asked 'What type of conflict is the Israeli-Palestinian conflict?' Respondents were grouped based on their answers to this question.
}

respondents who deemed the conflict religious were more likely to focus on religious issues in dispute (such as the al-Aqsa mosque or Western Wall). In contrast, those who thought of the conflict as nationalist were more likely to mention issues like a homeland or refer to the conflict sides as Israeli-Palestinian (Table I).

\section{Scale construction and review}

Based on the results of the focus group analysis, we constructed a detailed conflict framing scale to be used in Phase 2 of this research (Table II). This scale was then reviewed by a panel of five independent regional experts on Israeli-Palestinian issues and on protracted conflict in general. Items were included in the final scale only if all experts agreed that both (1) the measure was important to the competing frames and (2) it clearly differentiated each frame.

The focus group stage of this research produced two key findings. First, the parties involved in the conflict expressed three main conceptual frames through which they viewed the conflict - religious, nationalist or material. Second, the different parties to the conflict tended to view the conflict through distinct frames. While Jewish Israelis generally possessed mixed or material frames, Palestinians in both the West Bank and Israel were much more likely to possess a religious frame. However, these focus groups were conducted using a non-probability sample, with purposive oversampling of certain segments 
Table I. Prevalence of issue by conflict frame (Focus groups)

\begin{tabular}{|c|c|c|c|c|}
\hline Identified frame & Mentioned issue & Jews in Israel & $\begin{array}{l}\text { Palestinians } \\
\text { in Israel (PCI) }\end{array}$ & $\begin{array}{l}\text { Palestinians } \\
\text { in West Bank }\end{array}$ \\
\hline \multirow[t]{3}{*}{ Religious conflict } & Jerusalem, Al Aqsa, Temple Mount and holy places & $29 \%$ & $50 \%$ & $54 \%$ \\
\hline & Religious issues (Holy, God, God's promise, religious faith) & $59 \%$ & $36 \%$ & $31 \%$ \\
\hline & Conflict sides: Muslim vs. Jews & $12 \%$ & $14 \%$ & $15 \%$ \\
\hline \multirow[t]{5}{*}{ National conflict } & Homeland, Zionism, Nationalism & $33 \%$ & $21 \%$ & $31 \%$ \\
\hline & Refugees, Right of Return & $11 \%$ & $29 \%$ & $25 \%$ \\
\hline & Settlements or Occupation & $11 \%$ & $14 \%$ & $13 \%$ \\
\hline & Conflict sides: Arab vs. Israeli & $17 \%$ & $7 \%$ & $6 \%$ \\
\hline & Sovereignty, State/Country & $28 \%$ & $29 \%$ & $25 \%$ \\
\hline \multirow[t]{6}{*}{ Material conflict } & Power and control & $4.5 \%$ & $25 \%$ & $17 \%$ \\
\hline & Territory & $27 \%$ & $25 \%$ & $33 \%$ \\
\hline & Resources, Economy, Water & $36 \%$ & $25 \%$ & $33 \%$ \\
\hline & Borders & $4.5 \%$ & $25 \%$ & $17 \%$ \\
\hline & Political, Leaders & $14 \%$ & 0 & 0 \\
\hline & Security & $14 \%$ & 0 & 0 \\
\hline
\end{tabular}

The numbers presented here for Jewish citizens of Israel are lower than those for the other two groups because the recording device malfunctioned for two of the four Jewish Israeli focus groups. Thus, for these two groups, only the moderators' detailed notes were transcribed. Word counts generated using WordCounter.net.

${ }^{a}$ Across the three groups, conflict framing was mixed for 28 respondents. For example, subjects would mention refugees and prisoners as one of the main issues but describe the conflict as predominantly religious.

of each population in order to ensure diversity of views in the focus group setting. It was thus important to validate and expand on these results and the survey instrument using a quantitative large- $\mathrm{N}$ analysis, which was conducted in Phase 2.

\section{Phase 2: Conflict framing survey}

\section{Methods}

In September 2013, research assistants, fluent in Hebrew or Arabic, stopped passersby randomly on four university campuses and asked them to complete a questionnaire about the Israeli-Palestinian conflict. The Israeli participants, both Jews and Palestinians, were students at University of Haifa or Tel-Aviv University, while the West Bank participants included 98 students from the Arab American University of Jenin and 40 students from An-Najah National University in Nablus. The sample comprised 410 subjects, of whom 138 were West Bank Palestinians, 124 were PCIs, and 148 were Jewish citizens of Israel. The sample, overall, was approximately 58\% Muslim and 35\% Jewish, and 4\% Christian or Druze. $^{7}$ Women made up $54 \%$ of the sample and the

\footnotetext{
${ }^{7}$ Five Druze respondents were dropped from the analysis because they showed up in both the Jewish Israeli (2 respondents) and PCI sample (3 respondents).
}

average age was approximately 26. Detailed descriptive statistics are in Online appendix 2 (Table AII).

Though the student population in this study represents a limitation to generalizability (Sears, 1986), given the sociodemographic attributes of this population, ${ }^{8}$ recent studies have demonstrated that these samples often produce similar trends to those found in the general population (Altemeyer, 1996; Druckman, 2004; Druckman \& Kam, 2011; Mullinix et al., 2015). In the Israeli-Palestinian conflict, the use of student samples may also be less problematic than in contexts like the United States because students in Israel and the West Bank are typically older (attending either after army service or after working for several years), therefore representing a slightly more diverse age distribution than the stereotypical 19-year-old college sophomore. 9 Moreover, the fact that this survey was conducted with civilians living in the midst of active conflict increases the external validity - all students have actually experienced the

\footnotetext{
${ }^{8}$ For example, our Jewish Israeli sample is $70 \%$ secular, whereas in the broader Israeli society, secular Jews make up only $40 \%$, according to PEW. Because religiosity is associated with religious framing, it is possible that other segments of the Israeli electorate (e.g. the religious settler population) possess more of a religious frame.

${ }^{9}$ Our Palestinian samples are younger (WB median: 21, PCI median: 23) than the Jewish Israeli sample (median: 30), since Jewish Israelis attend college only after army service.
} 
Table II. Conflict framing scale

\begin{tabular}{|c|c|c|c|}
\hline & Religious & Nationalist & Material \\
\hline $\begin{array}{l}\text { 1. In your opinion, the } \\
\text { conflict in the Middle } \\
\text { East is a }\end{array}$ & 1: Muslim-Jewish conflict & 2: Arab-Zionist conflict & $\begin{array}{l}\text { 3: Conflict of resources, land, and } \\
\text { interests }\end{array}$ \\
\hline $\begin{array}{l}\text { 2. For you, the issue } \\
\text { of Jerusalem OR } \\
\text { al-Quds concerns }\end{array}$ & 1: The Holy City & $\begin{array}{l}\text { 2: The national capital of the } \\
\text { Jewish OR Arab people }\end{array}$ & $\begin{array}{l}\text { 3: The capital of an independent } \\
\text { Israeli OR Palestinian state }\end{array}$ \\
\hline $\begin{array}{l}\text { 3. For you, the issue of } \\
\text { the land is significant } \\
\text { because it is }\end{array}$ & $\begin{array}{l}\text { 1: The Promised Land/The } \\
\text { 'Isra and Mi'raj' land }\end{array}$ & $\begin{array}{l}\text { 2: The land of Israel OR Arab } \\
\text { occupied land }\end{array}$ & $\begin{array}{l}\text { 3: A politically and strategically } \\
\text { important land }\end{array}$ \\
\hline $\begin{array}{l}\text { 4. What is your vision } \\
\text { for this land? }\end{array}$ & $\begin{array}{l}\text { 1: A state that follows } \\
\text { religious law (halacha OR } \\
\text { as part of the caliphate) }\end{array}$ & $\begin{array}{l}\text { 2: A Jewish OR Arab national } \\
\text { state }\end{array}$ & $\begin{array}{l}\text { 3: A state for all its citizens, regardless } \\
\text { of nationality or religion, as long as } \\
\text { it is strong }\end{array}$ \\
\hline $\begin{array}{l}\text { 5. Who are the sides in } \\
\text { this conflict? }\end{array}$ & 1: Muslims vs. Jews & 2: Arabs vs. Zionists & 3: Palestinians vs. Israelis \\
\hline $\begin{array}{l}\text { 6. To you, the land of } \\
\text { Palestine OR Israel is: }\end{array}$ & $\begin{array}{l}\text { 1: The land of the Bible OR } \\
\text { Islamic property }\end{array}$ & $\begin{array}{l}\text { 2: The land of the Jewish OR } \\
\text { Arab people }\end{array}$ & $\begin{array}{l}\text { 3: The land of Israeli OR Palestinian } \\
\text { citizens }\end{array}$ \\
\hline $\begin{array}{l}\text { 7. The one issue you } \\
\text { will not compromise } \\
\text { on is: }\end{array}$ & 1: Jerusalem & $\begin{array}{l}\text { 2: A Jewish ethnic majority OR } \\
\text { the right of return }\end{array}$ & $\begin{array}{l}\text { 3: Defensible borders, access to } \\
\text { water, and territorial contiguity }\end{array}$ \\
\hline $\begin{array}{l}\text { 8. What character } \\
\text { should the country } \\
\text { have in the future? }\end{array}$ & $\begin{array}{l}\text { 1: A state run according to } \\
\text { religion }\end{array}$ & $\begin{array}{l}\text { 2: A state with a nationalistic } \\
\text { orientation }\end{array}$ & $\begin{array}{l}\text { 3: A strong state, able to sustain a } \\
\text { high quality of life, irrespective of } \\
\text { its national or religious character }\end{array}$ \\
\hline $\begin{array}{l}\text { 9. For you which is } \\
\text { more upsetting? }\end{array}$ & $\begin{array}{l}\text { 1: Surrendering the Temple } \\
\text { Mount and the Wailing } \\
\text { Wall to the Muslims OR } \\
\text { al-Quds to the Jews }\end{array}$ & $\begin{array}{l}\text { 2: The return of Palestinian } \\
\text { refugees OR abandoning the } \\
\text { return of Palestinian refugees }\end{array}$ & $\begin{array}{l}\text { 3: Surrendering significant territories } \\
\text { with vital resources and lands, } \\
\text { major traffic routes or water } \\
\text { reservoirs OR abandoning... }\end{array}$ \\
\hline $\begin{array}{l}\text { 10. When, in your } \\
\text { opinion, will the } \\
\text { conflict end? }\end{array}$ & $\begin{array}{l}\text { 1: The conflict with the } \\
\text { Muslims OR Jews will not } \\
\text { end until Judgment Day }\end{array}$ & $\begin{array}{l}\text { 2: The conflict with the Arabs } \\
\text { OR Israelis will end when: } \\
\text { The state of Israel is } \\
\text { recognized as the nation state } \\
\text { of the Jewish people OR the } \\
\text { Palestinians get their rights } \\
\text { and reclaim Arab territories }\end{array}$ & $\begin{array}{l}\text { 3: The conflict will end when there is } \\
\text { an agreement dividing the } \\
\text { resources and territories fairly }\end{array}$ \\
\hline $\begin{array}{l}\text { 11. The settlement } \\
\text { migration of Jews in } \\
\text { the early 20th century } \\
\text { was motivated by }\end{array}$ & 1: Religious motives & 2: National aspirations & $\begin{array}{l}\text { 3: Wanting to get a state with } \\
\text { strategic value }\end{array}$ \\
\hline $\begin{array}{l}\text { 12. Fighting the enemy, } \\
\text { for you, is }\end{array}$ & $\begin{array}{l}\text { 1: Fighting for religion OR } \\
\text { Jihad }\end{array}$ & $\begin{array}{l}\text { 2: Protecting Judaism as my } \\
\text { nationality OR nationalist } \\
\text { struggle over Arab land }\end{array}$ & $\begin{array}{l}\text { 3: Fighting to preserve and develop } \\
\text { resources and lands for the sake of } \\
\text { future generations }\end{array}$ \\
\hline $\begin{array}{l}\text { 13. Which motive } \\
\text { determines your } \\
\text { behavior in this } \\
\text { conflict }\end{array}$ & 1: Religion & 2: National interests & 3: Material interests \\
\hline
\end{tabular}

PCIs and West Bank Palestinians were presented with the second option (e.g. 'al Quds' as opposed to 'Temple Mount' in question 9). Labels of religious, nationalist, and material were not on the actual survey, but are presented here in order to clarify how responses were coded. Also, please note that this scale has been translated from the original Hebrew/Arabic as closely as possible. The original instrument in Hebrew and Arabic can be found in Online appendix 3.

impact of conflict in their daily lives and thus can be expected to have relevant political attitudes towards it.

Our dependent variable was assessed using items tapping potential compromises for peace along dimensions widely espoused by the international community for a peace agreement between Israelis and Palestinians, such as the principle of two states, mutual land swaps, joint sovereignty over the holy parts of Jerusalem and 
compromise on the issue of refugees (Peace Index, 2012). ${ }^{10}$ The wording for each of these questions was adapted specifically to suit each societal context. For example, key items were changed to reflect the relevant society's concerns - for Jewish Israelis the question about holy sites talks about 'the Temple Mount', while for Palestinians, it discusses 'al-Aqsa'. We used a six-item Likert scale from 1 to 6 , with 1 representing 'very much against' and 6 'very much support' $(\alpha=.89)$. The full scale in English and in the original Hebrew and Arabic is in Online appendix 3.

Using specific compromises is important to getting at the concept of political compromise for a few key reasons. First, 'the devil is in the details'. Polls consistently show high levels of support for peace among both Israelis and Palestinians, yet peace requires specific compromises that often enjoy much less popular support. In other words, compromise is easier to support when it is vague than when it is specific. We measure willingness to compromise as a scale (rather than each measure individually) because the parties would likely need to agree to all or most of these concessions for peace to be sustainable. Agreeing to one concession would be insufficient for conflict resolution and is thus not the core concept of interest. Second, this measure has been developed and validated among both Israelis and Palestinians by the Tel Aviv University Peace Index (2012) and is common in the literature on the Israeli-Palestinian conflict (see e.g. Halperin et al., 2011). Third, the specific compromises embodied in this measure reflect the broad-based international consensus on how the contours of a peace agreement might manifest. Finally, each question touches on core themes related to material, nationalist, and religious frames which can be found across conflicts. It is common for conflicts to involve issues such as border lines, control of holy spaces, resettlements of displaced people or refugees, and economic ties.

The main explanatory variable is our novel conflict framing scale developed in Phase I. This scale consists of 13 items (see Table II), designed to tap each of the three distinct conflict frames $(\alpha=0.74)$. Each item has three possible responses-materialist, nationalist, religious-tailored specifically for each group. For instance, on the question on the meaning of the land, an indication of a religious frame would be the land of the Bible for Jewish Israeli respondents versus the land of the Koran for Palestinian respondents. ${ }^{11}$ Likewise,

\footnotetext{
${ }^{10}$ https://en.idi.org.il/centers/1159/1520.

11 This reflects the findings from the focus group stage, where a religious framing of land frequently involved land paired with a
}

the language used in the Jewish Israeli version of the questionnaire was Jerusalem, whereas the Palestinian language used Al-Quds. We then formed three subscales, with each respondent receiving a value between 0 and 13 for each subscale based on the number of questions they answered corresponding to that frame.

To determine if conflict frames have an impact above and beyond other important demographic characteristics, we included covariates to account for their relative impact on willingness to compromise. We accounted for age, gender, education level, religiosity, and ideology or partisanship, which are most likely to impact both conflict frame and political attitudes. ${ }^{12}$ Exploring the connection between these variables is important to determining the discriminant validity of the conflict frames scale. Information on the measurement of the religiosity and ideology/partisanship covariates is in Online appen$\operatorname{dix} 3$.

\section{Results}

To begin, MANOVA ${ }^{13}$ pointed to significant differences between Palestinians (in both Israel and the West Bank) and Jewish Israelis in their general framing of the conflict $\left(\mathrm{F}_{6,810}=29.38, p<0.001\right)$ (Table AIV in the Online appendix). Post-hoc Scheffe tests showed that both PCIs and West Bank Palestinians were significantly more likely to frame the conflict as religious than were Jewish citizens of Israel. Jewish Israelis, however, were significantly more likely to frame the conflict as material than West Bankers and PCIs. Jewish Israelis were also significantly more likely to frame the conflict as nationalist than either West Bank Palestinians or PCIs. Interestingly, compared to PCIs, West Bankers were significantly more likely to frame the conflict as religious. In other words, Palestinian citizens of Israel were in between Jewish Israelis and West Bank Palestinians in their adoption of a religious frame of the conflict.

Categorized according to their most dominant frame, more than half (51\%) of Jewish Israelis saw the conflict as nationalist, while, in the West Bank, 64\% of Palestinians saw the conflict as having religious origins

religious indicator, such as 'holy land' or 'Muslim land', but a more material framing of land would refer to land alongside words like 'security' or 'contiguity'. These multiple meanings of land were carefully converted into the questionnaire.

${ }^{12}$ See for example Cohen-Zada, Margalit \& Rigbi (2016) for evidence on how religiosity impacts willingness to compromise in conflict.

${ }^{13}$ MANOVA (multiple ANOVA) was used here because we were interested in assessing differences between the groups on three related continuous dependent variables (the three conflict subscales). 


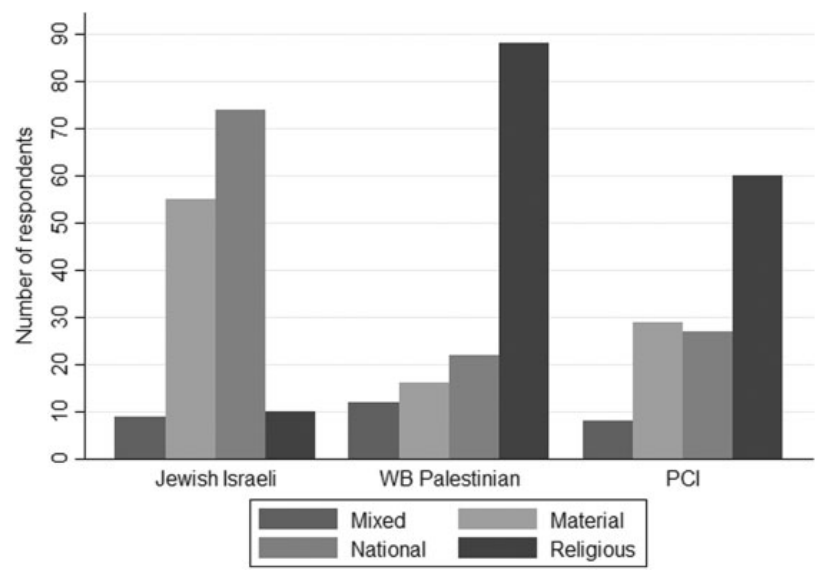

Figure 2. Different frames of the conflict between ethnic groups (Surveys)

Figure 2 plots the percentage of Jewish Israelis, PCIs, and West Bank Palestinians who categorize the conflict as predominantly material, religious or national in nature; 29 respondents who classified two frames as dominant (e.g. indicated the same number of statements for two different frames) are classified as mixed.

(Figure 2). This demonstrates a clear dichotomy: for Palestinians, the conflict is religious; for Jewish Israelis, it is primarily nationalist (ANOVA tables are in Online appendix 4).

The three groups had significantly different attitudes toward political compromise as well $\left(\mathrm{F}_{2,401}=53.06, p<\right.$ 0.001) (Figure 3). ${ }^{14}$ Namely, West Bank Palestinians were significantly less likely to express willingness to compromise $(\mathrm{M}=2.21 \mathrm{SD}=1.05)$ than were Jewish citizens of Israel $(\mathrm{M}=3.69 \mathrm{SD}=1.29)$ or PCIs $(\mathrm{M}=$ $2.98 \mathrm{SD}=1.27)$. A post-hoc Scheffe test confirmed that each group's attitude towards compromise was significantly different from the other two $(p<0.001)$.

Thus far, we established that both conflict frames and willingness to compromise vary by national context, but are these two related at the individual level? In other words, do conflict frames explain differences in willingness to compromise between individuals within a society? To address this question, we used regression analysis across all three parties to the conflict to examine the independent and interactive effects of conflict frame and nationality on willingness to compromise, accounting for gender, age, education, religiosity, and political ideology (Model 1, Table III). We then ran the same regression model for each party to the conflict separately (Models 2-4).

Examining the interaction patterns and breaking these results out by national group helps show which

\footnotetext{
${ }^{14}$ See also Table AV in the Online appendix.
}

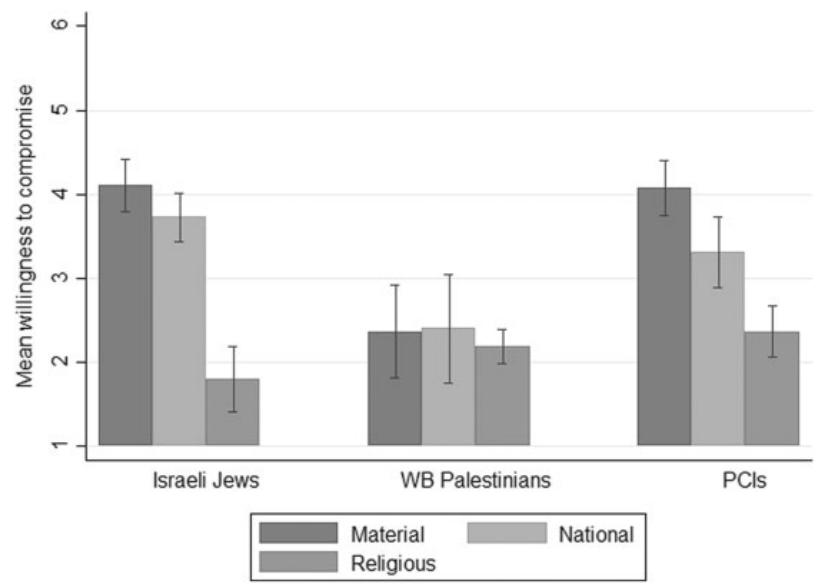

Figure 3. Impact of conflict frames on willingness to compromise (Surveys)

Figure 3 plots the mean levels of willingness to compromise by dominant frame and national group on a scale $1-6$ with 6 indicating a higher willingness to compromise. Lines represent $95 \%$ confidence intervals. Those with mixed frames are omitted.

group or groups espouse significantly different views based on their conflict frame. Both Jewish and Palestinian citizens of Israel are significantly less likely to support compromise when they possess a religious conflict frame versus a national one. However, while PCIs are significantly more supportive of compromise under a material frame as compared to a nationalist one, Jewish Israelis are not. Thus, for Jewish Israelis, nationalist and material frames are comparable in their association with support for compromise, but religious frames are distinct. Finally, for West Bank Palestinians, there is no significant effect of any conflict frame on willingness to compromise. This is a surprising and interesting finding. A visual representation of the data analyzed in the regression models is helpful to illustrate the different associations between conflict frames and willingness to compromise across the three groups (Figures 4 and 5).

This finding, that willingness to compromise is not affected by conflict frames among Palestinians in the West Bank, is theoretically significant. It implies that the effect of attitudinal prisms (conflict frames) is contingent on, and qualified by, the daily realities of occupation and asymmetric power relations. One potential reason for the different results may be that the overall physical and psychological conditions of the West Bank are very different from those within Israel proper. One plausible explanatory variable would be individual-level exposure to violence and to the quotidian happenings of daily occupation, which is much more prevalent in the West Bank. In additional analyses presented in Online 
Table III. Linear regression predicting willingness to compromise (Surveys)

\begin{tabular}{|c|c|c|c|c|}
\hline Variables & $\begin{array}{c}\text { (1) } \\
\text { Support for compromise } \\
\text { Full sample }\end{array}$ & $\begin{array}{c}\text { (2) } \\
\text { Support for compromise } \\
\text { Israeli Jews }\end{array}$ & $\begin{array}{c}\text { (3) } \\
\text { Support for compromise } \\
\text { WB Palestinians }\end{array}$ & $\begin{array}{c}\text { (4) } \\
\text { Support for compromise } \\
\text { PCIs }\end{array}$ \\
\hline Gender $($ female $=1)$ & $\begin{array}{c}-0.01 \\
(0.12)\end{array}$ & $\begin{array}{c}-0.19 \\
(0.17)\end{array}$ & $\begin{array}{c}0.32 \\
(0.21)\end{array}$ & $\begin{array}{c}-0.43 \\
(0.22)\end{array}$ \\
\hline $\operatorname{Age}^{a}$ & $\begin{array}{c}0.40 \\
(0.35)\end{array}$ & $\begin{array}{c}0.60 \\
(0.44)\end{array}$ & $\begin{array}{c}0.10 \\
(0.85)\end{array}$ & $\begin{array}{r}-0.04 \\
(0.67)\end{array}$ \\
\hline Religiosity (secular=1) & $\begin{array}{l}-0.18 \\
(0.16)\end{array}$ & $\begin{array}{c}0.20 \\
(0.21)\end{array}$ & $\begin{array}{l}-0.70^{*} \\
(0.32)\end{array}$ & $\begin{array}{c}-0.81^{*} \\
(0.32)\end{array}$ \\
\hline Partisanship $(\text { right }=1)^{b}$ & $\begin{array}{c}-0.87^{* * *} \\
(0.15)\end{array}$ & $\begin{array}{c}-1.64^{* * *} \\
(0.23)\end{array}$ & $\begin{array}{c}-0.23 \\
(0.25)\end{array}$ & $\begin{array}{c}-0.72^{* *} \\
(0.27)\end{array}$ \\
\hline Education $(\mathrm{BA}=1)$ & $\begin{array}{c}-0.03 \\
(0.16)\end{array}$ & $\begin{array}{c}0.26 \\
(0.25)\end{array}$ & $\begin{array}{c}-0.34 \\
(0.24)\end{array}$ & $\begin{array}{c}-0.01 \\
(0.41)\end{array}$ \\
\hline Material frame ${ }^{c}$ & $\begin{array}{l}1.91^{* *} \\
(0.63)\end{array}$ & $\begin{array}{c}-0.14 \\
(0.41)\end{array}$ & $\begin{array}{c}0.56 \\
(0.75)\end{array}$ & $\begin{array}{l}1.82^{* *} \\
(0.61)\end{array}$ \\
\hline Religious frame $e^{c}$ & $\begin{array}{c}-0.70 \\
(0.44)\end{array}$ & $\begin{array}{c}-1.52^{*} \\
(0.60)\end{array}$ & $\begin{array}{c}-0.37 \\
(0.47)\end{array}$ & $\begin{array}{r}-1.23^{*} \\
(0.49)\end{array}$ \\
\hline Group: ${ }^{d}$ & & & & \\
\hline Jewish Israeli & $\begin{array}{l}1.18^{* *} \\
(0.40)\end{array}$ & & & \\
\hline WB Palestinian & $\begin{array}{c}-1.09^{*} \\
(0.47)\end{array}$ & & & \\
\hline \multicolumn{5}{|l|}{ Interactions: } \\
\hline Jewish X Religious frame & $\begin{array}{c}-2.00^{* *} \\
(0.72)\end{array}$ & & & \\
\hline WBPal X Religious frame & $\begin{array}{c}1.09 \\
(0.59)\end{array}$ & & & \\
\hline Jewish X Material frame & $\begin{array}{c}-1.47 \\
(0.76)\end{array}$ & & & \\
\hline WBPal X Material frame & $\begin{array}{c}-1.01 \\
(0.93)\end{array}$ & & & \\
\hline Constant & $\begin{array}{l}3.09^{* * *} \\
(0.39)\end{array}$ & $\begin{array}{l}4.04^{* * *} \\
(0.39)\end{array}$ & $\begin{array}{l}2.46^{* * *} \\
(0.45)\end{array}$ & $\begin{array}{l}3.69^{* * *} \\
(0.56)\end{array}$ \\
\hline Observations & 365 & 134 & 120 & 111 \\
\hline R-squared & 0.487 & 0.537 & 0.130 & 0.468 \\
\hline
\end{tabular}

The table depicts the results of a linear regression model of support for compromise (ordinal scale 1-6) based on the above covariates.

${ }^{a}$ Age normalized from 0 to 1 .

${ }^{\mathrm{b}}$ Among West Bank Palestinians partisanship represents support for Hamas, among Palestinian citizens of Israel partisanship represents support for the Northern Front, and among Jewish citizens of Israel partisanship represents support for right-wing political parties.

${ }^{c}$ Ordinal variable of conflict frame, normalized from 0 to 1 . Nationalist Conflict Frame is the omitted category.

${ }^{\mathrm{d}} \mathrm{PCI}$ is the omitted category. Five Druze respondents excluded from analyses. ${ }^{*} p<0.05 ;{ }^{* *} p<0.01 ;{ }^{* *} p<0.001$.

appendix 5, we demonstrate that, indeed, West Bank Palestinians are significantly more exposed to daily political violence than both Jewish and Palestinian Citizens of Israel (Table AVI, Online appendix) and this has an independent, significant association with support for compromise (Table AVII).

A large body of work has demonstrated that exposure to violence is strongly linked to increases in militancy (see e.g. Canetti-Nisim et al., 2009, 2013). Likewise, a recent study (Longo, Canetti \& Hite-Rubin, 2014) suggested that daily encounters with the occupying side (e.g. when crossing military check points, or confronted by land seizure) may generate a feeling of humiliation that, in turn, can elicit militancy and reduce willingness to compromise for peace. These experiences are more common among West Bankers than Israelis. The invariance across conflict 


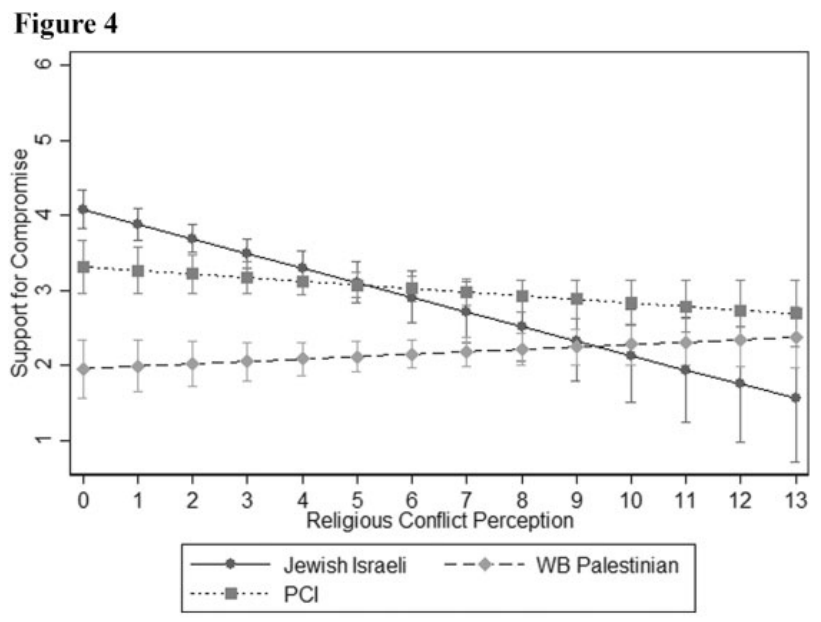

Figure 5

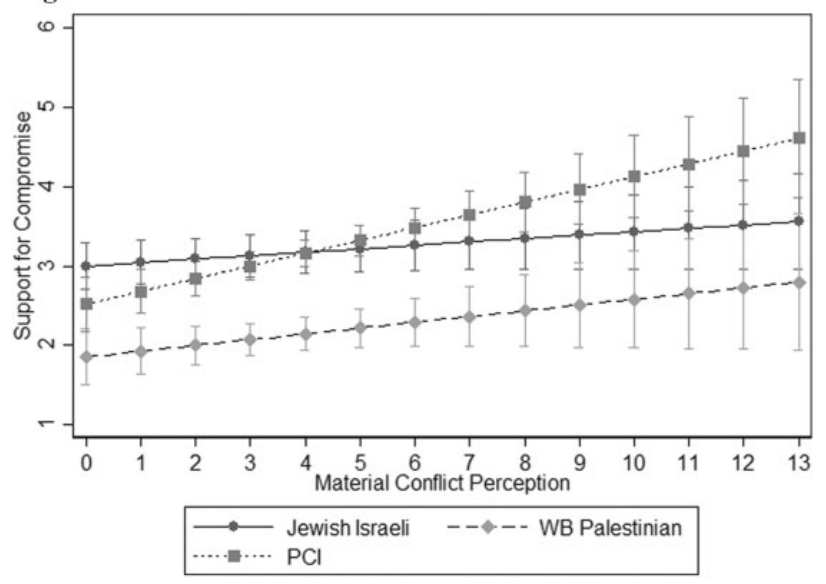

Figures 4 and 5. Correlation between religious and material frames and willingness to compromise across groups (Surveys) Figures 4 and 5 plot the regression lines for Table III (Model 1) for Jewish Israelis (solid line), West Bank Palestinians (dashed line), and PCIs (dotted line). Religious frames (Figure 4) are significantly associated with less willingness to compromise among Jewish Israelis and PCIs, but not among West Bank Palestinians. Material frames (Figure 5) are associated with significantly more willingness to compromise among PCIs, but not for Jewish Israelis or West Bank Palestinians

frames among West Bank Palestinians thus suggests that power dynamics and exposure to violence may play an important role in hardening attitudes toward political compromise (Hirsch-Hoefler et al., 2014).

The difference in the impact of conflict frame on views about peace between West Bankers and Israeli Palestinians is also likely tied up in the divergent paths of these two groups since the establishment of Israel. Palestinians in Israel are citizens of a state that is in conflict with their kin group (Palestinians), with which they have deep national, cultural, linguistic, and religious ties. This conflict between state and nation may lead
Israeli Palestinians to combine two competing ideals: a strong Palestinian identity with an equally powerful desire for full and equal recognition as Israeli citizens and integration in the (mostly Jewish) Israeli society (Al-Haj, Katz \& Shye, 1993). This duality, alongside their relatively more secure and stable daily life in Israel, likely accounts for the different impact of conflict frames on their attitudes.

In sum, findings show that among both Jews and Palestinians in Israel, conflict frames had a significant effect on their willingness to compromise - those with a material frame were significantly more likely to support compromise, ${ }^{15}$ while a religious frame had the opposite effect. Nationalist frames were in the middle in terms of their impact on willingness to compromise. Regardless of frames, West Bankers possessed a lower willingness to compromise compared to the other groups. Additionally, Jews and Palestinians differed in the frame they possessed; Israeli Jews were significantly more likely to frame the conflict as nationalist, while Palestinians (both in Israel and the West Bank) mainly possessed a religious frame.

\section{Implications for conflicts}

People fight to protect their national ideology, religion, or physical and economic wellness. Yet those living through protracted conflict often possess distinct conceptions of the fundamental nature and core issues of the conflict. Religious and nationalist frames can be just as, if not more, prevalent than material ones. This article accounts for the effect of competing conflict frames on the parties' willingness to compromise. It does so by using original focus groups and surveys among Israeli Jews and Palestinians, as well as West Bank Palestinians. Our findings suggest that frames of conflict are key to understanding potential pathways to peace, and religious framing is associated with greater militancy. In line with research that suggests that religion pushes partisans towards violence (Svensson, 2007; Fredman, Bastian \& Swann, 2017), this finding suggests that religious framing encourages resistance to compromise and, so, may impede the success of long-term peaceful negotiations. Acknowledging these diverse (often identity-based) frames is thus imperative for building support in those groups that find moving towards peace most challenging. However, the lower levels of willingness to compromise among Palestinian West Bankers, and the invariance of their attitudes across conflict frames, suggests that the

${ }^{15}$ Interestingly, this result was not significant for Jewish citizens of Israel, though the effect was in the hypothesized direction. 
explanatory power of conflict frames is not allencompassing and is qualified by the impact of daily realities, especially the hardships associated with prolonged occupation, on levels of militancy.

The debate over whether this conflict is unique or typical is burgeoning and far from reconciled. This conflict has unique characteristics that may lead to questions regarding the generalizability of results obtained from this conflict to other conflicts around the world. However, this is a concern not just for the current study, but for any case study (rather than cross-national) approach to the study of conflict. While it is overly ambitious to come up with a covering law, or general theory, based on a single case, this study can facilitate empirically based mid-range theories (Mjøset, 2006; Gerring, 2004) that set the ground for comparison of conflict framing dynamics across different conflicts.

Nonetheless, there are many factors that the IsraeliPalestinian conflict has in common with other conflicts around the world. For example, as with many protracted conflicts around the world, the Israeli-Palestinian conflict is an asymmetrical and visible conflict between two identity groups distinguished by culture, language, religion, and nationality. Territorial claims, historic grievances, entrenched sacredness, major violence in recent or living memory, historic injury that lives on in collective memory, and zero-sum attitudes towards claims are also key hallmarks of this conflict. Like many other conflicts, the parties are deeply embedded with each other, both physically and socially, arguably making the formation of two separate states a complex and challenging goal. Moreover, as with other protracted conflicts (e.g. Serbia and Kosovo, Cyprus, Northern Ireland), the Israeli-Palestinian conflict can be classified as encompassing one or more conflict frames (religious, national, and material). As such, the impact of conflict frames on the willingness of societies in other conflicts to compromise is likely also large.

Moreover, our noteworthy findings regarding the role of conflict frames may also pertain to protracted conflicts that have been formally resolved. For example, Northern Ireland's modern period of conflict started in the late 1960s and lasted more than three decades. However, despite a formal peace accord in 1998, divisive issues related to sectarian and national identity are still unresolved and contribute to occasional outbursts of disruption and violence.

This study points to individual-level outcomes as key micro-foundations of conflict. At the theoretical level, our work extends previous research on political attitudes among civilians living amid political violence by connecting conflict frames to attitudes towards peace and compromise. Relying on psycho-political approaches, we propose conflict frames as one key mechanism explaining these attitudes. Our results suggest that traditional approaches to conflict resolution by third-party practitioners and scholars may err in attempting to impose one (often material) conflict frame on the involved parties. This work thus provides a way forward for scholars of conflict and for practitioners to approach conflict resolution in deep protracted conflicts. Recognizing the varying and often opposing frames in a conflict is the first step to clearing the way on the path to peace. By extension, a successful pathway to peace must be a sophisticated one, tailored to address the way in which the core issues are uniquely framed by each party involved.

\section{Replication data}

The dataset, codebook, and do-files for the empirical analysis in this article, along with the Online appendix, can be found at http://www.prio.org/jpr/datasets. All analyses were conducted using STATA. For additional information, contact Daphna Canetti, dcanetti@poli.haifa.ac.il.

\section{Acknowledgements}

We thank As'ad Ghanem, Nadim Ruhana, Amal Jamal, Mary Totry, Sarah Ozacky-Lazar, Saleh Lutfi, Ibrahim Abu Jaber, and the numerous friends and colleagues who have helped along the way, including Ohad Shaked, Shani Fachter, and participants in the annual conference of the International Society of Political Psychology (Italy, July 2014).

\section{Funding}

This research was made possible, in part, by the support of the Center for Contemporary Studies - Umm al-Fahm, the School of Political Science at the University of Haifa. This research was further made possible by a grant from the Israel Science Foundation (487/08) and the US-Israel Binational Science Foundation (2009460).

\section{ORCID iD}

Daphna Canetti (D) https://orcid.org/0000-0003-07944090

Carly Wayne (D) https://orcid.org/0000-0002-4183-3 071 


\section{References}

Al-Haj, Majid; Elihu Katz \& Samuel Shye (1993) Arab and Jewish attitudes: Toward a Palestinian state. Journal of Conflict Resolution 37(4): 619-632.

Alesina, Alberto; Arnaud Devleeschauwer, William Easterly, Sergio Kurlat \& Romain Wacziarg (2003) Fractionalization. Journal of Economic Growth 8(2): 155-194.

Altemeyer, Robert (1996) The Authoritarian Specter. Cambridge, MA: Harvard University Press.

Anderson, Benedict (1983) Imagined Communities. London: Verso.

Appleby, Scott R (1999) The Ambivalence of the Sacred: Religion, Violence, and Reconciliation. Lanham, MD: Rowman \& Littlefield.

Atran, Scott; Robert Axelrod \& Richard Davis (2007) Sacred barriers to conflict resolution. Science 317(5841): 1039-1040.

Benford, Robert D \& David A Snow (2000) Framing processes and social movements: An overview and assessment. Annual Review of Sociology 26(1): 611-639.

Braun, Virginia \& Victoria Clarke (2006) Using thematic analysis in psychology. Qualitative Research in Psychology 3(2): 77-101.

Brecher, Michael (2017) Dynamics of the Arab-Israel Conflict. New York: Palgrave Macmillan.

Campbell, Donald T (1965) Ethnocentric and Other Altruistic Motives. Lincoln, NE: University of Nebraska Press.

Canetti, Daphna; Brian Hall, Carmit Rapaport \& Carly Wayne (2013) Exposure to political violence and political extremism. European Psychologist 18(4): 263-272.

Canetti, Daphna; Stevan E Hobfoll, Ami Pedahzur \& Eran Zaidise (2010) Much ado about religiosity: Heightened support for political violence by failure to conserve. Journal of Peace Research 45(5): 575-587.

Canetti-Nisim, Daphna; Eran Halperin, Keren Sharvit \& Steven E Hobfoll (2009) A new stress-based model of political extremism: Personal exposure to terrorism, psychological distress, and exclusionist political attitudes. Journal of Conflict Resolution 53(3): 363-389.

Caplan, Neil (2011) The Israel-Palestine Conflict: Contested Histories (Vol. 16). New York: John Wiley \& Sons.

Carter, David B (2010) The strategy of territorial conflict. American Journal of Political Science 54(4): 969-987.

Cederman, Lars-Erik \& Luc Girardin (2007) Beyond fractionalization: Mapping ethnicity onto nationalist insurgencies. American Political Science Review 101(1): 173-185.

Cohen-Zada, Danny; Yotam Margalit \& Oren Rigbi (2016) Does religiosity affect support for political compromise? International Economic Review 57(3): 1085-1106.

Collier, Paul \& Anke Hoeffler (2004) Greed and grievance in civil war. Oxford Economic Papers 56(4): 563-595.
Cyr, Jennifer (2016) The pitfalls and promise of focus groups as a data collection method. Sociological Methods \& Research 45(2): 231-259.

Dowty, Alan (2005) Israel/Palestine. Cambridge: Polity.

Druckman, James (2001) On the limits of framing effects: Who can frame? Journal of Politics 63(4): 1041-1066.

Druckman, James (2004) Political preference formation: Competition, deliberation, and the (ir)relevance of framing effects. American Political Science Review 98(4): 671-686.

Druckman, James \& Cindy D Kam (2011) Students as experimental participants: A defense of the 'narrow data base'. In: James N Druckman, Donald P Green, James H Kuklinski \& Arthur Lupia (eds) Cambridge Handbook of Political Science. Cambridge, Cambridge University Press, 41-57.

Dunning, Tristan (2015) Islam and resistance: Hamas, ideology and Islamic values in Palestine. Critical Studies on Terrorism 8(2): 284-305.

Fearon, James D (1995) Rationalist explanations for war. International Organization 49(3): 379-414.

Fearon, James D \& David Laitin (2003) Ethnicity, insurgency, and civil war. American Political Science Review 97(1): 75-90.

Fox, Jonathan \& Shmuel Sandler (2004) Bringing Religion into International Relations. New York: Palgrave Macmillan.

Fredman, Leah A; Brock Bastian \& William B Swann Jr (2017) God or country? Fusion with Judaism predicts desire for retaliation following Palestinian stabbing Intifada. Social Psychological and Personality Science 8(8): 882-887.

Gellner, Ernest (1983) Nationalism and the Two Forms of Cohesion in Complex Societies. London: British Academy.

Gerring, John (2004) What is a case study and what is it good for? American Political Science Review 98(2): 341-354.

Ghanem, As'ad (2010) Palestinian Politics after Arafat: A Failed National Movement. Bloomington, IN: Indiana University Press.

Goddard, Stacie E (2006) Uncommon ground: Indivisible territory and the politics of legitimacy. International Organization 60(1): 35-68.

Goertz, Gary \& Paul F Diehl (1992) Territorial Changes and International Conflict. London \& New York: Routledge.

Guest, Greg; Emily E Namey \& Marilyn L Mitchell (2012) Collecting Qualitative Data: A Field Manual for Applied Research. New York: Sage.

Haklai, Oded (2007) Religious-nationalist mobilization and state penetration: Lessons from Jewish settlers' activism in Israel and the West Bank. Comparative Political Studies 40(6): 713-739.

Halperin, Eran; Alexandra G Russell, Kali H Trzesniewski, James J Gross \& Carol S Dweck (2011) Promoting the Middle East peace process by changing beliefs about group malleability. Science 333(6050): 1767-1769. 
Harvey, Oliver J; Jack B White, William R Hood \& Carolyn W Sherif (1961) Intergroup Conflict and Cooperation: The Robbers Cave Experiment (Vol. 10). Norman, OK: University Book Exchange.

Hassner, Ron (2009) War on Sacred Grounds. Ithaca, NY: Cornell University Press.

Hirsch-Hoefler, Sivan; Daphna Canetti, Carmit Rapaport \& Steven E Hobfoll (2014) Conflict will harden your heart: Exposure to violence, psychological distress, and peace barriers in Israel and Palestine. British Journal of Political Science 46(4): 845-859.

Huntington, Samuel (1993) The clash of civilizations? Foreign Affairs 72(3): 22-49.

Inbari, Motti (2012) Messianic Religious Zionism Confronts Israeli Territorial Compromises. New York: Cambridge University Press.

Isaacs, Matthew (2016) Sacred violence or strategic faith? Disentangling the relationship between religion and violence in armed conflict. Journal of Peace Research 53(2): 211-225.

Juergensmeyer, Mark (1993) Why religious nationalists are not fundamentalists. Religion 23(1): 85-92.

Kapiszewski, Diana; Lauren M MacLean \& Benjamin L Read (2015) Field Research in Political Science: Practices and Principles. Cambridge: Cambridge University Press.

Longo, Matthew; Daphna Canetti \& Hite-Rubin Nancy (2014) A checkpoint effect? Evidence from a natural experiment on travel restrictions in the West Bank. American Journal of Political Science 58(4): 1006-1023.

Lunt, Peter \& Sonia Livingstone (1996) Rethinking focus groups in media and communications research. Journal of Communication 46(2): 79-98.

Manekin, Devorah; Guy Grossman \& Tamar Mitts (forthcoming) Contested ground: Disentangling material and symbolic attachment to territory. Political Science Research \& Methods. https://doi.org/10.1017/psrm. 2018.22.

Maoz, Moshe (2014) The role of the Temple Mount/ Al-Haram Al-Sharif in the deterioration of Muslim-Jewish relations. Approaching Religion 4(2): 60-70.

Miller, Benjamin (2005) When and how regions become peaceful: Potential theoretical pathways to peace. International Studies Review 7(2): 229-267.

Mishal, Shaul \& Avraham Sela (2006) The Palestinian Hamas: Vision, Violence, and Coexistence. New York: Columbia University Press.

Mjøset, Lars (2006) A case study of a case study: Strategies of generalization and specification in the study of Israel as a single case. International Sociology 21(5): 735-766.

Morgan, David L (1996) Focus Groups as Qualitative Research, Vol. 16. New York: Sage.

Mullinix, Kevin J; Thomas J Leeper, James N Druckman \& Jeremy Freese (2015) The generalizability of survey experiments. Journal of Experimental Political Science 2(2): 109-138.
O’Brien, Keith (1993) Improving survey questionnaires through focus groups. In: David L Morgan (ed.) Successful Focus Groups: Advancing the State of the Art. Los Angeles, CA: Sage, 105-117.

Onwuegbuzie, Anthony J; Wendy B Dickinson, Nancy L Leech \& Annmarie G Zoran (2009) A qualitative framework for collecting and analyzing data in focus group research. International Journal of Qualitative Methods 8(3): 1-21.

Peace Index (2012) Tel-Aviv University (https://en.idi. org.il/centers/1159/1520, retrieved on 16 December 2012).

Philpott, Daniel (2007) Explaining the political ambivalence of religion. American Political Science Review 101(3): 505-525.

Rasler, Karen \& William Thompson (2006) Contested territory, strategic rivalries, and conflict escalation. International Studies Quarterly 50(1): 145-167.

Rubin, Aviad (2014) Bifurcated loyalty and religious actors' behavior in democratic politics: The case of post-1967 religious Zionism in Israel. Religion, State and Society 42(1): 46-65.

Sambanis, Nicholas (2001) Do ethnic and nonethnic civil wars have the same causes? A theoretical and empirical inquiry (Part 1). Journal of Conflict Resolution 45(3): 259-282.

Sears, David O (1986) College sophomores in the laboratory: Influences of a narrow data base on social psychology's view of human nature. Journal of Personality and Social Psychology 51(3): 515-530.

Selby, Jan (2003) Dressing up domination as 'cooperation': The case of Israeli-Palestinian water relations. Review of International Studies 29(1): 121-138.

Seul, Jeffrey (1999) 'Ours is the way of god': Religion, identity, and intergroup conflict. Journal of Peace Research 36(5): 553-569.

Smith, Anthony D (2000) The sacred dimension of nationalism. Millennium: Journal of International Studies 29(3): 791-814.

Snow, David A \& Robert D Benford (1988) Ideology, frame resonance, and participant mobilization. International Social Movement Research 1(1): 197-217.

Svensson, Isak (2007) Fighting with faith: Religion and conflict resolution in civil wars. Journal of Conflict Resolution 51(6): 930-949.

Tajfel, Henri \& John Turner (1982) The social psychology of intergroup relations. Annual Review of Psychology 33(1): $1-39$.

Tessler, Mark (2009) A History of the Israeli-Palestinian Conflict. Bloomington, IN: Indiana University Press.

Varshney, Ashutosh (2003) Nationalism, ethnic conflict, and rationality. Perspectives on Politics 1(1): 85-99.

Vasquez, John \& Brandon Valeriano (2010) Classification of interstate wars. Journal of Politics 72(2): 292-309.

Vaughn, Sharon; Jeanne Shay Schumm \& Jane M Sinagub (1996) Focus Group Interviews in Education and Psychology. New York: Sage. 
Ward, Victoria M; Jane T Bertrand \& Lisanne Brown (1991) The comparability of focus group and survey results: Three case studies. Evaluation Review 15(2): 266-283.

DAPHNA CANETTI, b. 1969, PhD in Political Science (University of Haifa, 2003); Professor \& Head, School of Political Science (University of Haifa); research interests: political psychology, cyber terrorism, terrorism and political violence, intractable conflict.

IBRAHIM KHATIB, b. 1989, PHD in Political Science (Humboldt University of Berlin, 2018); postdoctoral researcher as an Academic Visitor at the School of Global and Area Studies, University of Oxford; main interests:
Arab-Israeli conflict, politics of the Middle East, religion and democracy, violent conflicts, and political psychology.

AVIAD RUBIN, b. 1974, PhD in Political Science (McGill University, 2010); Senior Lecturer, School of Political Science, University of Haifa; research interests: the intersection of regime theory and politics of identity, religion and politics, the Arab-Israeli conflict.

CARLY WAYNE, b. 1987, MSc in Political Science (University of Michigan, 2015); PhD candidate (University of Michigan); research interests: psychology of political violence, micro-foundations of public opinion, conflict processes, terrorism, foreign policy decisionmaking. 